Case Report

\title{
Congenital Tarsal Kink Syndrome: Literature Review and Case Report
}

\author{
Speranța Schmitzer 1,2,*, Sorin-Dorin Haidu ${ }^{2}$, Ioana Claudia Popteanu ${ }^{2}$ (D) and Anca Angela Simionescu ${ }^{1,3}$ (D) \\ 1 Department of Obstetrics and Gynecology, Carol Davila University of Medicine and Pharmacy, \\ 050474 Bucharest, Romania; anca.simionescu@umfcd.ro \\ 2 Department of Ophthalmology, Emergency Clinical Eye Hospital, 010464 Bucharest, Romania; \\ haidusorin@gmail.com (S.-D.H.); oana.popteanu@gmail.com (I.C.P.) \\ 3 Department of Obstetrics and Gynecology, Filantropia Clinical Hospital, 011132 Bucharest, Romania \\ * Correspondence: speranta.sch@gmail.com
}

check for updates

Citation: Schmitzer, S.; Haidu, S.-D.; Popteanu, I.C.; Simionescu, A.A. Congenital Tarsal Kink Syndrome: Literature Review and Case Report. Children 2022, 9, 31. https://doi.org/ 10.3390/children9010031

Academic Editor: Sari A. Acra

Received: 23 November 2021

Accepted: 21 December 2021

Published: 1 January 2022

Publisher's Note: MDPI stays neutral with regard to jurisdictional claims in published maps and institutional affiliations.

Copyright: (c) 2022 by the authors. Licensee MDPI, Basel, Switzerland. This article is an open access article distributed under the terms and conditions of the Creative Commons Attribution (CC BY) license (https:// creativecommons.org/licenses/by/ $4.0 /)$.

\begin{abstract}
Background: The congenital tarsal kink syndrome is a rare form of congenital upper eyelid entropion associated with cardiovascular, musculoskeletal or central nervous system disorders. This syndrome must be recognized and surgically treated as a perinatal emergency to avoid associated complications-corneal ulcer, corneal leucoma, secondary amblyopia and decreased vision among children. Methods: A literature review was conducted to clarify the diagnosis particularities and the corrective surgery options of the congenital entropion on the upper eyelid. Results: Four relevant studies were found by researching the Web of Science and PubMed databases up to November 2021 for "congenital tarsal kink syndrome" and "congenital upper eyelid entropion". Conclusions: In this paper, we present a case of congenital unilateral entropion of the upper left eyelid in the context of a tarsal kink syndrome in a one-month old infant, manifested by the absence of eyelashes on the upper eyelid of the left eye, hyperlacrimation and conjunctival hyperemia. Essential in managing the upper eyelid entropion is protecting the cornea. Furthermore, correcting a tarsal kink is eminently surgical, choosing between open or closed procedures. Herein, we address the difficulty in the timely diagnosis of this uncommon condition and make formal recommendations based on all reported cases.
\end{abstract}

Keywords: congenital entropion; tarsal kink; corneal ulceration; corneal macula; ciliary edge

\section{Introduction}

The congenital tarsal kink syndrome is a very rare form of congenital upper eyelid entropion [1,2]. Physical examination revealed the presence of a horizontal tarsal kink determining the internal rotation of the upper eyelid margin, the cilia coming into contact with the ocular globe and causing secondary blepharospasm, hyperlacrimation, photophobia and corneal ulcerations [2,3]. The average age at the time of diagnosis varies between 1 and 60 weeks [2]. It mainly affects boys and is mainly unilateral, but it can also be bilateral $[2,3]$. It can be associated with systemic cardiovascular conditions or central nervous system disorders [3-5]. The condition must be recognized and surgically treated as an emergency to avoid associated complications-corneal ulcer, corneal leucoma and secondary amblyopia [6-8].

This paper aims to highlight diagnostic and treatment approaches for the uncommon congenital tarsal kink syndrome and to offer arguments for universal ophthalmologic evaluation of newborns at birth.

\section{Materials and Methods}

Systematic research of the literature between 1984 and 2021 was conducted in the PubMed, Web of Science, Embase and MEDLINE (Medical Literature Analysis and Retrieval System Online) databases to select full-length articles published in peer-reviewed journals up to November 2021. The keywords included in the search strategy were "congenital 
tarsal kink syndrome" and "congenital upper eyelid entropion". We limited inclusion to clinically reported cases or series of cases that fulfill the diagnosis of congenital eyelid entropion related to congenital tarsal kink syndrome, isolated or associated with a genetic or chromosomal abnormality. Full-text articles were included. We excluded articles related to other causes of congenital or noncongenital entropion, such as disinsertion of the eyelid retractors, insufficiency of verticality of the posterior lamella, spastic, involutional or cicatricial entropion.

The study was conducted in accordance with the Declaration of Helsinki, and the mother signed the informed consent for the publication of this case.

\section{Results}

We found a total of 20 relevant articles. We selected only nine full-text articles. We excluded 11 articles because no full text was available. Twenty-seven cases of congenital entropion have been identified in the context of tarsal kink syndrome, 16 male and 11 female (Table 1). The mean age of diagnosis ranges between the first week of life and 60 months. Of these patients, $77.78 \%(n=21)$ of cases are unilateral and $22.23 \%(n=6)$ are bilateral. The referral diagnosis was congenital entropion for thirteen cases, corneal ulceration for six cases, corneal opacity for five cases, corneal erosion for two patients and conjunctivitis for one patient. Surgical techniques included closed procedures for nine patients and open procedures for sixteen patients. An ocular patch was used in two cases.

Table 1. Characteristics of congenital tarsal kink syndrome reported cases.

\begin{tabular}{|c|c|c|c|c|c|c|c|}
\hline Study & $\begin{array}{l}\text { Patient } \\
\text { Number }\end{array}$ & $\begin{array}{c}\text { Age of } \\
\text { Diagnosis }\end{array}$ & Gender & Laterality & $\begin{array}{c}\text { Referral } \\
\text { Diagnosis }\end{array}$ & Associations & $\begin{array}{l}\text { Surgical } \\
\text { Technique }\end{array}$ \\
\hline $\begin{array}{l}\text { Vahdani } \\
\text { et al., } 2016 \\
\text { [9] }\end{array}$ & 1 & 9 days & Male & Right & $\begin{array}{c}\text { Corneal } \\
\text { opacity \& red } \\
\text { eye }\end{array}$ & Isolated & $\begin{array}{c}\text { Everting sutures } \\
\text { through a } \\
\text { posterior approach }\end{array}$ \\
\hline \multirow{6}{*}{$\begin{array}{l}\text { Naik et al., } \\
2007 \text { [2] }\end{array}$} & 2 & 8 weeks & Male & Right & $\begin{array}{l}\text { Congenital } \\
\text { entropion }\end{array}$ & Isolated & $\begin{array}{l}\text { Transconjunctival } \\
\text { horizontal } \\
\text { tarsotomy with } \\
\text { marginal rotation }\end{array}$ \\
\hline & 3 & 4 weeks & Male & Left & Corneal scar & Isolated & $\begin{array}{l}\text { Transconjunctival } \\
\text { horizontal } \\
\text { tarsotomy with } \\
\text { marginal rotation }\end{array}$ \\
\hline & 4 & 1 week & Female & Right & Conjunctivitis & Isolated & $\begin{array}{c}\text { Transconjunctival } \\
\text { horizontal } \\
\text { tarsotomy with } \\
\text { marginal rotation }\end{array}$ \\
\hline & 5 & 6 weeks & Male & Left & $\begin{array}{l}\text { Congenital } \\
\text { entropion }\end{array}$ & Isolated & $\begin{array}{l}\text { Transconjunctival } \\
\text { horizontal } \\
\text { tarsotomy with } \\
\text { marginal rotation }\end{array}$ \\
\hline & 6 & 36 months & Male & Left & Corneal scar & Isolated & $\begin{array}{l}\text { Transconjunctival } \\
\text { horizontal } \\
\text { tarsotomy with } \\
\text { marginal rotation }\end{array}$ \\
\hline & 7 & 60 months & Male & Right & Corneal scar & Isolated & $\begin{array}{l}\text { Transconjunctival } \\
\text { horizontal } \\
\text { tarsotomy with } \\
\text { marginal rotation }\end{array}$ \\
\hline
\end{tabular}


Table 1. Cont.

\begin{tabular}{|c|c|c|c|c|c|c|c|}
\hline Study & $\begin{array}{l}\text { Patient } \\
\text { Number }\end{array}$ & $\begin{array}{c}\text { Age of } \\
\text { Diagnosis }\end{array}$ & Gender & Laterality & $\begin{array}{l}\text { Referral } \\
\text { Diagnosis }\end{array}$ & Associations & $\begin{array}{l}\text { Surgical } \\
\text { Technique }\end{array}$ \\
\hline $\begin{array}{l}\text { Aziz et al., } \\
2006[1]\end{array}$ & 8 & 17 days & Female & Right & $\begin{array}{c}\text { Congenital } \\
\text { entropion }\end{array}$ & Distichiasis & Everting sutures \\
\hline $\begin{array}{l}\text { Batur et al., } \\
2017 \text { [4] }\end{array}$ & 9 & 5 months & Male & Bilateral & $\begin{array}{l}\text { Congenital } \\
\text { entropion }\end{array}$ & $\begin{array}{l}\text { Wiedemann- } \\
\text { Rautenstrauch } \\
\text { syndrome }\end{array}$ & Everting sutures \\
\hline $\begin{array}{l}\text { Lucci et al., } \\
2003 \text { [10] }\end{array}$ & 10 & 2 months & Female & Right & $\begin{array}{l}\text { Corneal } \\
\text { opacity }\end{array}$ & $\begin{array}{c}\text { Trisomy } 13 \text { (Patau } \\
\text { syndrome) } \\
\text { microcephaly, } \\
\text { characteristic } \\
\text { phenotype } \\
\text { associated sloping } \\
\text { forehead, } \\
\text { flattened occiput, } \\
\text { micrognathia, flat } \\
\text { nose, short neck } \\
\text { and atrial septal } \\
\text { defect }\end{array}$ & $\begin{array}{l}\text { Temporary eyelid } \\
\text { margin suture }\end{array}$ \\
\hline $\begin{array}{c}\text { Demirel } \\
\text { et al., } 2012 \\
{[11]}\end{array}$ & 11 & 3 months & Female & Right & $\begin{array}{l}\text { Congenital } \\
\text { entropion }\end{array}$ & Isolated & $\begin{array}{c}\text { Modified } \\
\text { temporary eyelid } \\
\text { margin suture }\end{array}$ \\
\hline $\begin{array}{c}\text { McElevanney } \\
\text { et al., } 1994 \\
{[12]}\end{array}$ & 12 & 7 days & Female & Bilateral & Corneal ulcer & Isolated & Unfold pressure \\
\hline $\begin{array}{l}\text { Price and } \\
\text { Collins } \\
1987[3]\end{array}$ & 13 & 26 weeks & Male & Right & $\begin{array}{l}\text { Congenital } \\
\text { entropion }\end{array}$ & Isolated & Suture rotation \\
\hline \multirow{10}{*}{$\begin{array}{c}\text { Sires } 1999 \\
{[8]}\end{array}$} & 14 & Birth & Female & Left & Corneal ulcer & Isolated & $\begin{array}{c}\text { Anterior lamellar } \\
\text { reposition }\end{array}$ \\
\hline & 15 & Birth & Female & Bilateral & $\begin{array}{c}\text { Congenital } \\
\text { entropion }\end{array}$ & Isolated & $\begin{array}{l}\text { Kink resection, } \\
\text { suture rotation }\end{array}$ \\
\hline & 16 & Birth & Male & Right & $\begin{array}{l}\text { Congenital } \\
\text { entropion }\end{array}$ & Isolated & Suture rotation \\
\hline & 17 & Birth & Male & Bilateral & $\begin{array}{l}\text { Congenital } \\
\text { entropion }\end{array}$ & Isolated & Suture rotation \\
\hline & 18 & 1 week & Female & Bilateral & Corneal ulcer & Isolated & Kink excision \\
\hline & 19 & 2 weeks & Male & Right & $\begin{array}{c}\text { Congenital } \\
\text { entropion }\end{array}$ & Isolated & $\begin{array}{l}\text { Margin suture } \\
\text { rotation }\end{array}$ \\
\hline & 20 & 2 weeks & Male & Bilateral & $\begin{array}{l}\text { Corneal } \\
\text { erosion }\end{array}$ & Cardiac defect & $\begin{array}{l}\text { Levator repair, } \\
\text { crease fixation }\end{array}$ \\
\hline & 21 & 4 weeks & Female & Right & $\begin{array}{l}\text { Congenital } \\
\text { entropion }\end{array}$ & Isolated & $\begin{array}{l}\text { Incise kink, suture } \\
\text { rotation, upper lid } \\
\text { tightening }\end{array}$ \\
\hline & 22 & 4 weeks & Female & Left & $\begin{array}{l}\text { Congenital } \\
\text { entropion }\end{array}$ & Isolated & $\begin{array}{l}\text { Incise kink, suture } \\
\text { rotation }\end{array}$ \\
\hline & 23 & 4 weeks & Female & Left & $\begin{array}{l}\text { Congenital } \\
\text { entropion }\end{array}$ & Isolated & $\begin{array}{c}\text { Incise kink, suture } \\
\text { rotation }\end{array}$ \\
\hline
\end{tabular}


Table 1. Cont.

\begin{tabular}{|c|c|c|c|c|c|c|c|}
\hline Study & $\begin{array}{c}\text { Patient } \\
\text { Number }\end{array}$ & $\begin{array}{c}\text { Age of } \\
\text { Diagnosis }\end{array}$ & Gender & Laterality & $\begin{array}{c}\text { Referral } \\
\text { Diagnosis }\end{array}$ & Associations & $\begin{array}{c}\text { Surgical } \\
\text { Technique }\end{array}$ \\
\hline & 24 & 6 weeks & Male & Left & Corneal ulcer & Isolated & $\begin{array}{c}\text { Tarsal fracture and } \\
\text { suture }\end{array}$ \\
\hline & 25 & 6 weeks & Male & Right & Corneal ulcer & Isolated & $\begin{array}{l}\text { Posterior approach, } \\
\text { kink excision }\end{array}$ \\
\hline & 26 & 10 weeks & Male & Right & Corneal ulcer & Isolated & $\begin{array}{l}\text { Weaken kink, } \\
\text { suture rotation, } \\
\text { supratarsal } \\
\text { rotation }\end{array}$ \\
\hline & 27 & 44 weeks & Male & Right & $\begin{array}{l}\text { Corneal } \\
\text { erosion }\end{array}$ & Isolated & Unfold kink, patch \\
\hline
\end{tabular}

\section{Case Presentation}

We present the case of a male two-month old patient admitted for corneal ulceration on their left eye. The pregnancy and childbirth were uneventful, the child was born at term by the vaginal way, and no associated maternal systemic diseases were reported. The mother noticed the static eyelid anomaly. The neonatologist did not consider the condition an emergency and assured the parents it would spontaneously remit. At the age of 1 month, the mother brought the child to the ophthalmologist with the following symptoms: absence of eyelashes on the upper eyelid of the left eye, hyperlacrimation and conjunctival congestion. After an examination conducted under general anesthesia, the diagnosis was corneal erosion and spastic entropion in the left eye. The recommended treatment included antibiotic and cycloplegic eye drops, a therapeutic contact lens was applied, and the patient was scheduled for a check-up after 14 days. However, as the mother noticed the spontaneous expulsion of the therapeutic contact lens a few hours after being released, the recurrence and worsening of photophobia and hyperlacrimation, associated with changes in the transparency of the cornea, the patient returned to the clinic after seven days. As a result, the decision was made to have the patient examined by the oculoplasty department.

Physical examination revealed spastic entropion of the upper eyelid on the entire eyelid length, accentuated in the inner two-third, hypertrophy of the pretarsal orbicularis muscle and the absence of the upper eyelid fold in the left eye. No static or dynamic eyelid anomalies were revealed in the right eye or in the lower left eyelid.

Examination under general anesthesia allowed for a difficult eversion of the upper eyelid, using the Desmarres retractor, which revealed a horizontal tarsal scar band located at approximately 2-3 $\mathrm{mm}$ from the edge of the eyelid, in the middle of the tarsus, accompanied by a shortening of the posterior upper eyelid lamella and the inward twisting of the ciliary margin. It also revealed a central corneal leucoma measuring approximately $6 \mathrm{~mm}$ in diameter and a central corneal ulceration measuring approximately $2 \mathrm{~mm}$ in diameter (Figure 1A,B). Applying pressure with the finger on the upper eyelid caused the eversion of the eyelid, but only for a short period, approximately $30 \mathrm{~s}$, after which the entropion set back. 

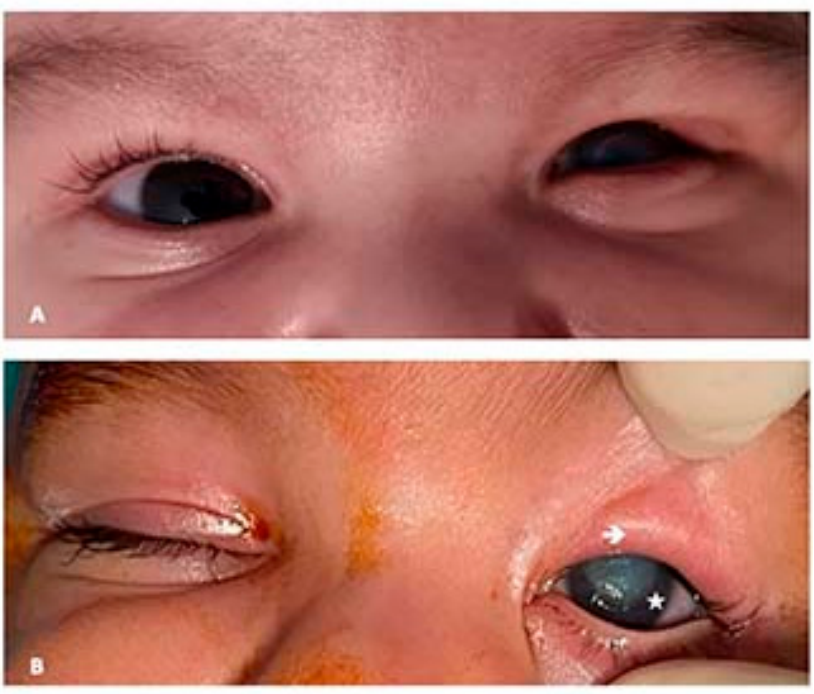

Figure 1. (A) Clinical aspect upon presentation. (B) Pre-op clinical aspect. To notice the absence of the cilia on the ciliary margin, the hypertrophy of the upper pretarsal orbicularis muscle and the central corneal leucoma (personal collection).

Upon clinical examination, the diagnosis was set-tarsal kink syndrome-and the recommendation was surgical correction. The preanesthetic pediatric visit, however, revealed an upper airways infection, so the surgery was postponed until the infection had been cleared. In the meantime, the patient underwent thorough investigations in order to exclude associated systemic pathologies, including a conjunctival smear test that later showed no pathological germs. Moreover, topical treatment was carried out at home during this time, consisting of frequent administration of corneal trophic and epithelial regeneration substances.

After 14 days, the patient returned to the clinic and underwent corrective surgery of the congenital entropion on the upper eyelid, which consisted of making a cutaneousmuscular incision 2-3 $\mathrm{mm}$ from the ciliary margin, revealing the tarsal plate and excising the fibrotic band on the entire length and width of the tarsal plate. Since there was no resulting relaxation of the eyelid, a partial disinsertion of the levator aponeurosis was performed, at which time the eyelid returned to a normal position. Three absorbable 5/0 sutures were made on the trajectory: skin (ciliary margin) — upper tarsal plate—skin (ciliary margin) in the inner, median and outer third of the upper eyelid (Figure 2).

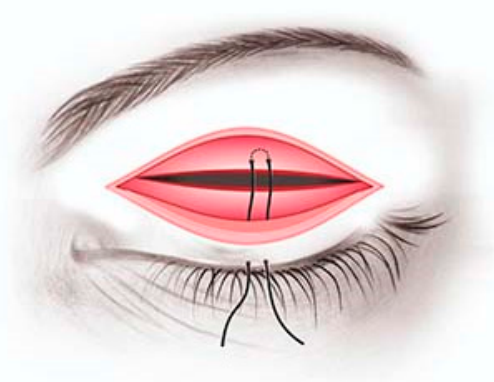

Figure 2. Schematic representation of the suture trajectory: skin (ciliary margin)—upper tarsal plate-skin (ciliary margin) (picture by Speranța Schmitzer).

The intervention was completed with the excision of a hypertrophied orbicular pretarsal muscle extension, a therapeutic contact lens placement and the execution of a blepharorrhaphy (Figure 3A-F). 

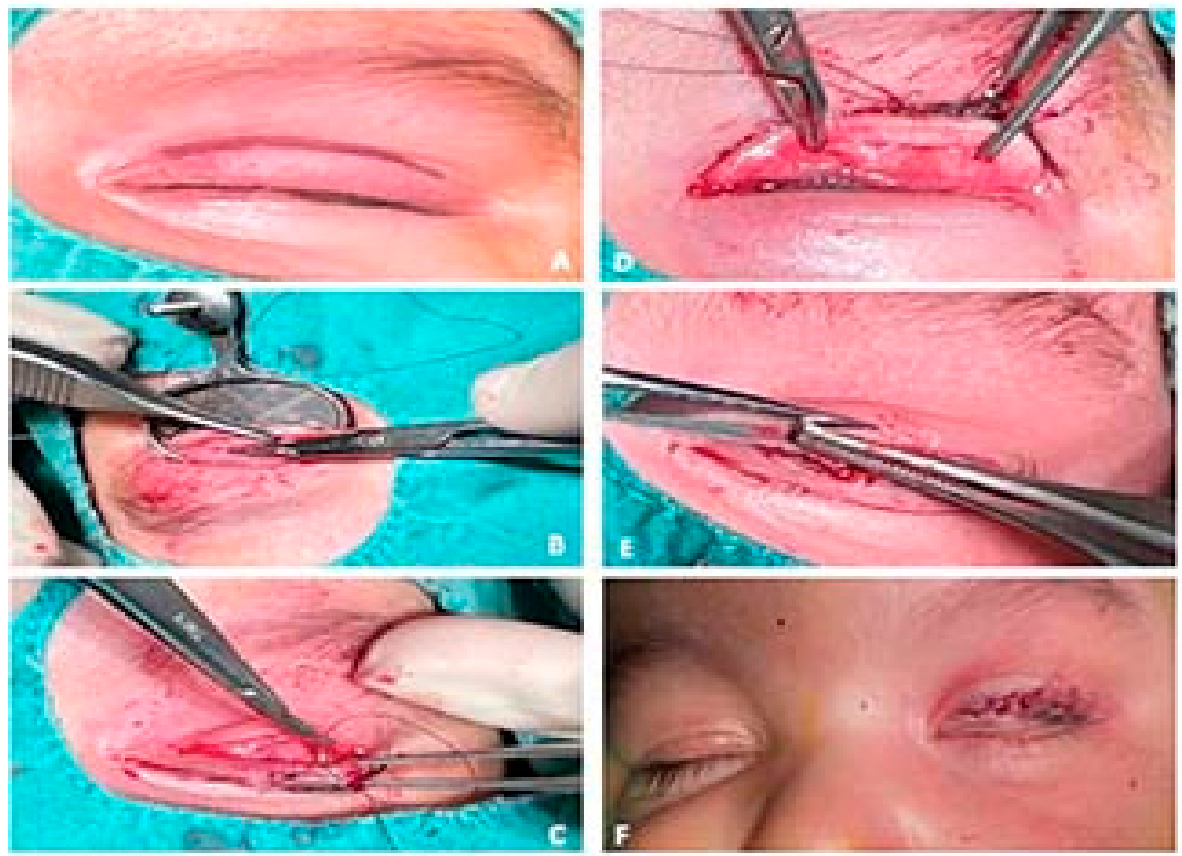

Figure 3. Main surgery steps. (A) Marking the incision $5 \mathrm{~mm}$ above the free eyelid edge; (B) The excision of the fibrous band on the entire length and width of the tarsal plate; (C,D) Application of sutures on the trajectory: skin (ciliary margin)—upper tarsal plate—skin (ciliary margin) in the inner, median and outer third of the upper eyelid; (E) Excision of a hypertrophied orbicular pretarsal muscle extension; (F) Cutaneous suture (personal collection).

The post-op evolution was favorable. Four days after surgery, the blepharorrhaphy sutures were removed and the upper eyelid retained its normal position with a slight eyelid ptosis. The recommendation was to apply a light topical anti-inflammatory steroid treatment, corneal trophic and epithelial regeneration substances with emulsified vitamin A and artificial tears with hyaluronic acid. At the one-week check-up, the upper eyelid maintained its normal position, the corneal ulceration was healed and the corneal leucoma was in remission.

At the one-month check-up, the evolution was spectacular; the eyelid maintained its normal position, the eyelid slit was symmetric to the one of the congener eye, and the cornea regained its transparency almost completely, with a persisting central corneal macula. The therapeutic contact lens was removed, and the recommendation was made to continue the topical treatment with emulsified vitamin A, artificial tears with hyaluronic acid and light anti-inflammatory steroid treatment to recover corneal transparency.

One month and a half after surgery, the evolution continues to be very good, with no subjective symptomatology (Figure 4). 

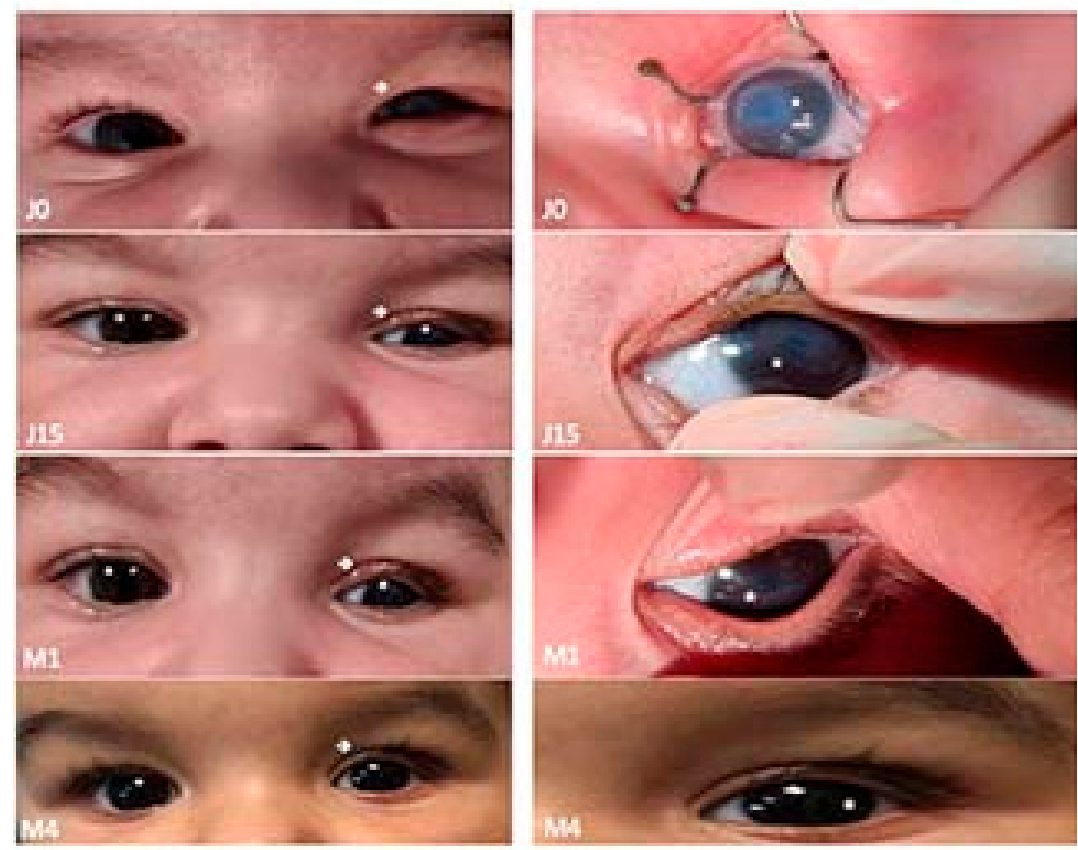

Figure 4. Favorable evolution and improvement in the position of the upper eyelid of the left eye and disappearance of the central corneal leucoma four months after surgery (personal collection).

\section{Discussion}

Our surgical technique for congenital tarsal kink syndrome is innovative because the sutures do not include the lower edge of the tarsal plate, only the ciliary skin edge and the upper tarsal edge were associated with the excision of a hypertrophied orbicular pretarsal muscle extension.

The congenital upper eyelid entropion is rare, and, in most cases, it is associated with a shortening of the posterior eyelid lamella of different etiologies [1,2]. Although it was described as early as 1948 by Kettesy, its etiology still remains uncertain [1,3,8]. Multiple etiopathogenesis mechanisms were put forth, of which we mention the overreaction of the marginal fibers of the orbicularis muscle, causing the infolding of the tarsal plate in utero. Moreover, primary tarsal defects, disinsertion of the levator aponeurosis, eyelid disjunctions in utero and exogenous mechanical causes in utero [1,13]. Sires et al. have suggested an acute eyelid trauma during childbirth due to right occiput anterior presentation [8]. Although most cases do not associate systemic pathologies, they can appear, which is why these patients must be carefully examined by a pediatrician who would insist on the cardiovascular, musculoskeletal and nervous systems [3,4,7]. In the United Kingdom, screening for eye pathologies $72 \mathrm{~h}$ after birth is offered by ophthalmologists to newborns, using clinical eye examination and direct ophthalmoscopy to check for light reflex and red reflex [14]. Costs for universal newborn eye screening must be balanced against the potential cost for children's care to improve visual outcomes in case of missed diagnosis [15].

The surgical goal in patients with tarsal kink syndrome is to obtain a normal eyelid statics. Regardless of the surgical technique used-closed or open procedures for entropion correction - the results reported in the reviewed articles are good in terms of eyelid statics. The patient's visual prognosis is related to the timeline of diagnosis and treatment initiation, as well as the associated corneal changes (erosion, ulceration, perforation).

Most patients with tarsal kink syndrome are isolated cases that do not have another associated pathology. There are the situations when this condition can be found in some syndromes or other pathologies.

In comparison to our surgical technique, some of the techniques described in Table 1 use closed procedures with everting sutures $[1,4,9]$, while the open procedure is also different, using a transconjunctival approach with horizontal tarsotomy and marginal rotation [2]. Essential to managing the upper eyelid entropion is protecting the cornea by applying 
corneal trophic substances-eyewashes, gels and ointments [5]. The placement of a therapeutic contact lens is not a first intention solution because it is quickly expelled [1]. Another course of action that is not recommended is protecting the cornea with a dressing [5,7]. A therapeutic contact lens can be used with success in patient postoperative management.

Correcting a tarsal kink is eminently surgical-whether we are talking about open or closed procedures [2,3]. The goal is to weaken the tarsal fibrosis and to evert the eyelid margin. Multiple techniques have been described in case presentations. The surgery was a success every single time, indicating that the correction of the tarsal kink does not depend on the procedure [2]. The open procedures described are represented by: the excision of the fibrotic band associated with eversion sutures, the horizontal transection of the tarsal plate associated with eversion sutures, the repositioning of the anterior lamella, horizontal tarsotomy with marginal rotation, lamellar tarsoplasty and resection of the anterior lamella [1,3-5]. Closed procedures include different types of eyelid eversion sutures, intermarginal tarsorrhaphy and the mechanical extension of the tarsal plate followed by a temporary tarsorrhaphy on the grey line in the first few days of life $[2,6]$.

The prognosis of the patients is very good in the case of early diagnosis and treatment, and irreversible corneal damage is thus avoided $[1,2,6]$. In this case, despite a relatively late intervention, after the installation of corneal damage, the result was very good, and we will continue to monitor the evolution of the patient's visual acuity and refraction as they grow.

\section{Conclusions}

The congenital tarsal kink syndrome is a serious and rare disease that can have severe consequences for the patient if it is not treated properly and in time. The "invisibility" of the ciliary edge and the absence of the upper eyelid fold can be important diagnostic indicators for the neonatologist and pediatrician. A simple maneuver involving the eversion of the upper eyelid, revealing the posterior side of the eyelid, allows for early diagnosis. The tarsal kink must be taken into consideration when making the etiologic differential diagnosis of congenital corneal opacities and corneal ulcerations. Surgical treatment applied in time is effective and reduces the risk of corneal leucomas.

Author Contributions: Conceptualization, S.S., S.-D.H. and I.C.P.; methodology, S.S., S.-D.H., A.A.S. and I.C.P.; software, S.S., S.-D.H., A.A.S. and I.C.P.; validation, S.S., S.-D.H., A.A.S. and I.C.P.; formal analysis, S.S., S.-D.H., A.A.S. and I.C.P.; investigation, S.S., S.-D.H. and I.C.P.; data curation, S.S., S.-D.H. and I.C.P.; writing-original draft preparation, S.S.; S.-D.H. and I.C.P.; writing-review and editing, S.S., S.-D.H. and A.A.S.; visualization, S.S., S.-D.H., A.A.S. and I.P; supervision, S.S. and A.A.S.; project administration, S.S. All authors have read and agreed to the published version of the manuscript.

Funding: This research received no external funding.

Institutional Review Board Statement: Not applicable.

Informed Consent Statement: Written informed consent has been obtained from the mother's patient to publish this paper.

Conflicts of Interest: The authors declare no conflict of interest.

\section{References}

1. Aziz, S.; Bhatt, P.R.; Lavy, T.; Dutton, G. A simple correction for congenital tarsal kink associated with distichiasis. J. AAPOS 2006, 10, 281-282. [CrossRef] [PubMed]

2. Naik, M.N.; Honavar, S.G.; Bhaduri, A.; Linberg, J.V. Congenital horizontal tarsal kink: A single-center experience with 6 cases. Ophthalmology 2007, 114, 1564-1568. [CrossRef] [PubMed]

3. Price, N.C.; Collin, J.R. Congenital horizontal tarsal kink: A simple surgical correction. Br. J. Ophthalmol. 1987, 71, 204-206. [CrossRef] [PubMed]

4. $\quad$ Batur, M.; Seven, E.; Çinal, A.; Yaşar, T. Wiedemann-Rautenstrauch Syndrome with Bilateral Tarsal Kink: Three Sutures for Correction. J. Craniofac. Surg. 2017, 28, 831-832. [CrossRef] [PubMed]

5. Warner, N.J.; Wasserman, B.N.; Lai, Y.H. Bedside repair of congenital upper eyelid entropion: A variation of the Quickert suture technique. Am. J. Ophthalmol. Case Rep. 2016, 4, 57-59. [CrossRef] [PubMed] 
6. Yuksel, D.; Kosker, M. The surgical treatment of congenital tarsal kink syndrome associated with corneal ulcer. Ophthalmic Surg. Lasers Imaging. 2011, 42, e126-e128. [CrossRef] [PubMed]

7. Luchs, J.I.; Laibson, P.R.; Stefanyszyn, M.A.; Rapuano, C.J.; Cohen, E.J.; Schnall, B.M.; Raber, I.M. Infantile ulcerative keratitis secondary to congenital entropion. Cornea 1997, 16, 32-34. [CrossRef] [PubMed]

8. Sires, B.S. Congenital horizontal tarsal kink: Clinical characteristics from a large series. Ophthalmic Plast. Reconstr. Surg. 1999, 15, 355-359. [CrossRef] [PubMed]

9. Vahdani, K.; Konstantinidis, A.; Thaller, V.T. A Simple New Technique for Treatment of Tarsal Kink Syndrome. Ophthalmic Plast. Reconstr. Surg. 2017, 33 (Suppl. 1), S77-S79. [CrossRef] [PubMed]

10. Lucci, L.M.; Fukumoto, W.K.; Alvarenga, L.S. Trisomy 13: A rare case of congenital tarsal kink. Ophthalmic Plast. Reconstr. Surg. 2003, 19, 408-410. [CrossRef] [PubMed]

11. Demirel, S.; Cemal, F.; Penpe, G.F. Modified Temporary Eyelid Margin Suture for Correction of Congenital Horizontal Tarsal Kink. A Novel Surgical Technique. Ophthalmic Plast. Reconstr. Surg. 2012, 28, 300-302. [CrossRef] [PubMed]

12. McElvanney, A.M.; Adhikary, H.P.; Ridgway, A.E.; Tullo, A.B. Congenital tarsal kink: A rare cause of neonatal corneal ulcers. Eye 1994, 8, 702-703. [CrossRef] [PubMed]

13. Chen, W.P. Oculoplastic Surgery: The Essentials; Thieme: Stuttgart, NY, USA, 2001. [CrossRef]

14. Mansoor, N.; Mansoor, T.; Ahmed, M. Eye pathologies in neonates. Int. J. Ophthalmol. 2016, 9, 1832-1838. [CrossRef] [PubMed]

15. Chee, R.; Chan, R. Universal newborn eye screening: An effective strategy to improve ocular health? Eye 2018, 32, 50-52. [CrossRef] [PubMed] 